\title{
Molecular detection of tick-borne rickettsial and protozoan pathogens in domestic dogs from Turkey
}

Munir Aktas ${ }^{1 *}$, Sezayi Özübek ${ }^{1}$, Kürşat Altay ${ }^{1,2}$, Neval Duygu Sayin Ipek ${ }^{3}$, İbrahim Balkaya ${ }^{4}$, Armagan Erdem Utuk, Akın Kırbas ${ }^{6}$, Sami Şimsek ${ }^{1}$ and Nazir Dumanlı ${ }^{1}$

\begin{abstract}
Background: Canine tick-borne parasites have emerged in recent years, showing a wider geographic distribution and increased global prevalence. In addition to their veterinary importance, domestic dogs play an important role in the transmission cycles of some agents by acting as reservoirs and sentinels. This study investigated Babesia, Theileria, Anaplasma, and Ehrlichia species in asymptomatic dogs in ten provinces of Turkey.

Methods: DNA obtained from blood samples collected from 757 domestic dogs (243 stray, 351 shelter, 163 pet) of both sexes and various ages were evaluated using PCR and reverse line blotting (RLB) assays.

Results: Of the 757 dogs tested, 41 (5.4\%) were found to be infected with one or more parasites. Ehrlichia canis (37/757, 4.9\%) was the most common canine tick-borne pathogen, followed by Anaplasma platys (4/757, 0.5\%). Babesia canis and Theileria annulata were each detected in $1(0.13 \%)$ sample. Combined infection of E. canis and A. platys was detected in $2(0.3 \%)$ samples. The prevalence of tick-borne pathogens was higher in adult dogs (6.8\%) than in those under one year old (3.1\%). Difference in infection rate of male and female dogs was not significant. Pet dogs had a lower prevalence of infection (1.2\%) compared to stray (7.4\%) and shelter dogs (6\%) although the difference between stray and shelter dogs was not significant.

Conclusions: Babesia canis, T. annulata, A. platys, and E. canis species were identified at the molecular level in dogs in several provinces of Turkey, with $E$. canis being the most common species among tick-borne pathogens. Detailed studies should be conducted regarding the existence and prevalence of $B$. canis and Dermacentor reticulatus in eastern Turkey.
\end{abstract}

Keywords: Dog, Babesia canis canis, Anaplasma platys, Ehrlichia canis, Theileria annulata, RLB

\section{Background}

Rickettsia and protozoa are transmitted by ixodid ticks, and cause both clinical and subclinical infections of their hosts. Among these, babesiosis, anaplasmosis, and ehrlichiosis are significant infectious diseases of dogs [1]. Canine babesiosis is characterized by fever, anemia, hemoglobinuria, thrombocytopenia, jaundice, and functional disorders of organs [2]. Several species of Babesia may infect dogs, including large (e.g., B. canis, B. rossi, B. vogeli) and small (e.g., B. gibsoni, B. conradae) forms

\footnotetext{
* Correspondence: maktas@firat.edu.tr

'Department of Parasitology, College of Veterinary Medicine, Firat University, 23119 Elazig, Turkey

Full list of author information is available at the end of the article
}

of Babesia [3]. The geographic distribution of these species is closely related to the distribution of vector ticks. Babesia canis occurs in countries with a temperate climate [4], B. rossi is found in South Africa [5], and $B$. vogeli in regions in which Rhipicephalus sanguineus sensu lato exists [3]. These species are transmitted by Dermacentor, Rhipicephalus, and Haemaphysalis ticks [6].

Anaplasmosis, caused by Anaplasma phagocytophilum and Anaplasma platys, and ehrlichiosis, caused by Ehrlichia canis, Ehrlichia chaffeensis, Ehrlichia ewingii, and Ehrlichia muris, are emerging infectious diseases affecting dogs in many parts of the world and can be manifested as acute or non-clinical infections [7]. Weight loss, anorexia, pale mucous membranes, high fever, lethargy, lymphadenopathy, 
and splenomegaly are the most commonly observed clinical signs [8]. Ehrlichia canis is transmitted by Rh. sanguineus s.l. and has also been experimentally transmitted by some Dermacentor species [9]. The DNA of $A$. platys was reported in Rh. sanguineus s.l. ticks [5].

Tick-borne diseases can be diagnosed from clinical signs and microscopic examination of stained blood smears. However, as the morphology of the pathogens in the host cell is similar, species cannot be distinguished by microscopic examination [10]. Microscopic examination of stained blood smears has very limited sensitivity [11-13]. In addition, inclinic serology tests do not differentiate active infection from prior exposure [14], therefore, molecular techniques have become the preferred method for detection of tick-borne hemoparasites in vertebrates and ticks [15-21].

Canine tick-borne disease caused by Babesia, Anaplasma, and Ehrlichia have been reported in Turkey [22-26], but there is limited information regarding prevalence of these pathogens. The objective of this survey was to investigate the frequency and distribution of tick-borne protozoan and bacterial pathogens in asymptomatic domestic dogs from ten provinces of Turkey.

\section{Methods}

\section{Study site and collection of samples}

This study was conducted on asymptomatic domestic dogs in coastal (Sakarya, Kocaeli, Mersin, Giresun, and İzmir) and inland (Elazig, Diyarbakır, Erzurum, Ankara, Nevşehir) provinces of Turkey (Figure 1). The coastal provinces have temperate oceanic climate (with warm, wet summers and cool to cold, wet winters) and Mediterranean climate (with hot, dry summers and mild to cool, wet winters). At lower levels of these provinces, the forest is mainly deciduous, often associated with evergreen shrubs, but at higher levels conifers increase or become dominant. The inland provinces have a continental climate (with hot summers and colder winters), and steppic habitats represent the major natural vegetation. The average annual precipitation in Aegean (İzmir), Mediterranean (Mersin) and Black Sea (Sakarya, Kocaeli, Giresun) coasts varies from 580 to $2200 \mathrm{~mm}$, whereas $400 \mathrm{~mm}$ in the inland provinces [27]. The altitude of the study sites ranges from 2 (İzmir) to 1890 (Erzurum) m above sea level. There is no information regarding the estimated dog population in both coastal and inland provinces. Hovewer, at least 49 dogs in each province were sampled.

Blood samples $(3 \mathrm{~mL})$ were collected in EDTA tubes from 757 domestic dogs (243 stray, 351 from shelters, 163 pets). The study was conducted in cooperation with municipal dog shelters, Firat University Veterinary Faculty, and private veterinary clinics. Sample collection was conducted from June 2010 to October 2012. Blood samples were collected from both male and female dogs of different breeds and various ages. Gender, age, and origin (stray, shelter, pet) of the dogs were recorded at sampling time. Age was estimated from body size and teeth, with those aged 6 months to 1 year designated as young, and those from 1 to 7 years considered adults. Based on behavior, all dogs appeared healthy, but detailed clinical examinations were not conducted.

\section{Ethical approval}

This study was approved by Firat University experimental animal ethic committee (approved protocol no. 16.02.2010-15).

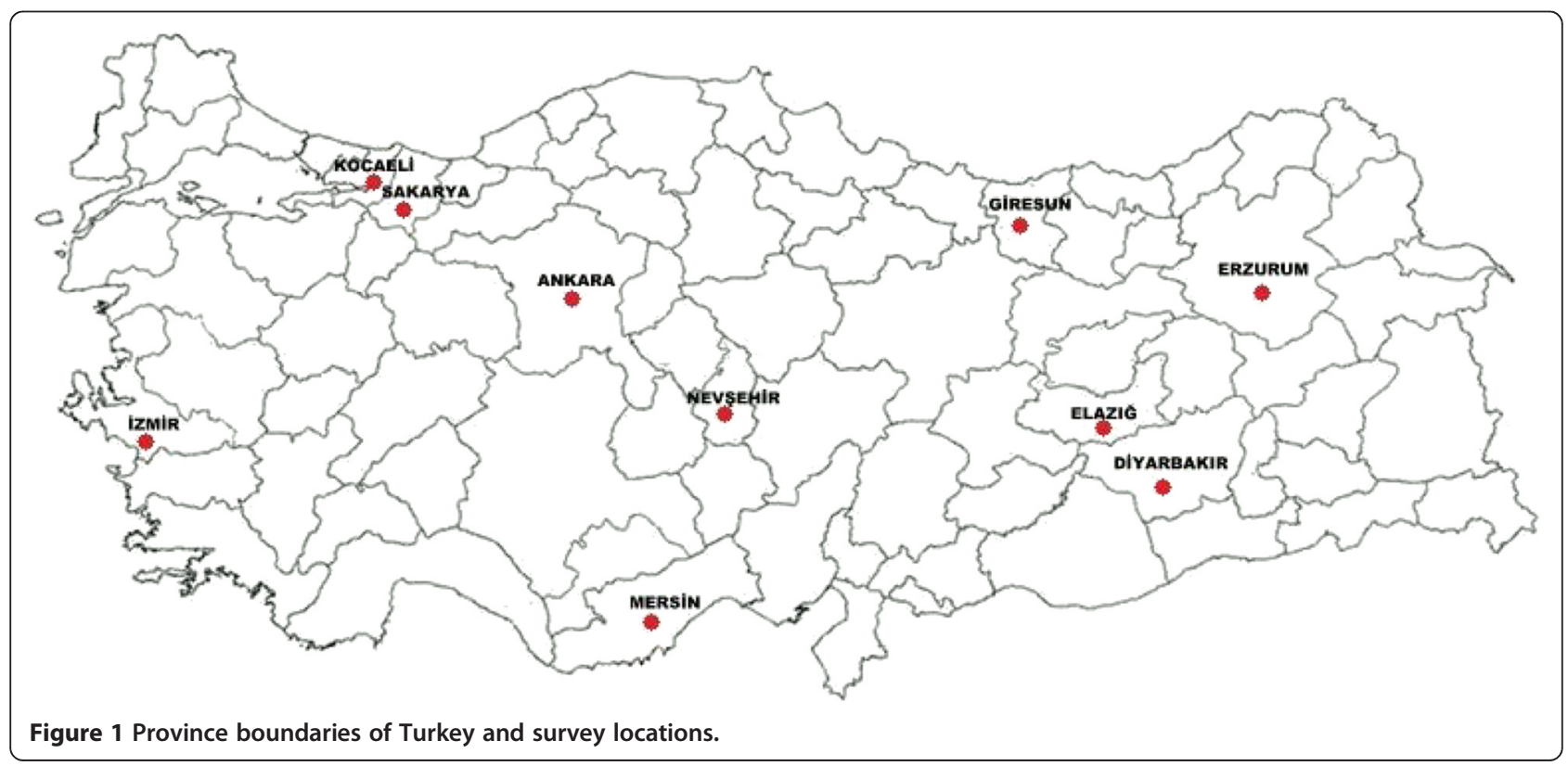




\section{Microscopic examination}

Immediately after sample collection, 348 thin blood smears were prepared for microscopic examination. The smears were fixed with methanol for $5 \mathrm{~min}$ and then stained with 5\% May-Grunwald Giemsa in buffer solution for $30 \mathrm{~min}$. The stained slides were examined under oil immersion at $1000 \times$ on a Nikon microscope for the presence of piroplasms (Babesia, Theileria) and inclusion bodies (Anaplasma, Ehrlichia). This was done by a person who was blinded to the molecular results.

\section{DNA isolation and PCR amplification}

Genomic DNA extraction was performed using QIAamp DNA Blood Mini kits (Qiagen, Hilden, Germany) according to the manufacturer's protocol. Negative control purifications using sterilized de-ionized water were performed to monitor cross-contamination for each batch of 18 samples. A total of 15 DNA samples were randomly selected for the quantification. DNA concentrations $(\mathrm{ng} / \mu \mathrm{L})$ and purity $\left(A_{260 \mathrm{~nm}} / A_{280 \mathrm{~nm}}\right)$ were determined by spectrophotometry (NanoDrop ${ }^{\circ}$ ND- 2000 UV/Vis Spectrophotometer, Thermo Fisher Scientific Inc., Wilmington, Delaware, USA). In order to minimize potential risks of contamination, DNA extractions, PCR preparation, PCR amplification, and agarose gel electrophoresis were performed in separate rooms. Genus-specific primers, RLBF2/RLBR2, were used to amplify a fragment of 460-540 bp of the 18S SSU rRNA gene of the V4 region of Theileria and Babesia species [28]. For identification of Anaplasma and Ehrlichia species, the primers 16S8FE and BGA1B were used to amplify a fragment of approximately $500 \mathrm{bp}$ of the 16S rRNA gene of the V1 region of Anaplasma and Ehrlichia spp., as described by Schouls et al. [15]. The PCR reactions were performed in PCR Sprint (Thermo Electron Corporation, USA), using a touchdown PCR program as previously described [29].
For positive control of $B$. canis, PCR positive amplicon obtained a dog naturally infected with Babesia spp. were purified and sequenced to identify amplified organisms. Sequencing result indicated that the amplicon was similar to the corresponding B. canis sequences deposited in GenBank. This template was used as a positive control DNA for B. canis. DNA from E. canis which tested positive by RLB and DNA sequencing (KF034789) obtained in a previous study [26] were used as positve control. In order to determine the detection limit of the PCR based RLB assay, serial ten-fold dilutions (from $10^{-1}$ to $10^{-10}$ ) of E. canis and B. canis canis positive control DNA (starting at 22.7 and $11.8 \mathrm{ng} / \mu \mathrm{l}$, respectively) were prepared in sterilized deionized water and tested. The lowest DNA concentration that yielded an RLB signal was considered as the limit of detection of the PCR based RLB assay. Positive controls with the lowest detection limit were included in every assay run. Sterilized de-ionized water was used as negative control.

\section{Reverse line blotting (RLB)}

To detect Theileria, Babesia, Anaplasma, and Ehrlichia species, a reverse line blot (RLB) hybridization was performed on the PCR products, as described previously [18]. Briefly, to $20 \mu \mathrm{L}$ of the PCR products, $2 \mathrm{X} \mathrm{SSPE} / 0.1 \%$ SDS was added to a final volume of $150 \mu \mathrm{L}$ and held in the Thermal Cycler at $99^{\circ} \mathrm{C}$ for $10 \mathrm{~min}$ and denatured for RLB hybridization. Catch-all and species specific probes were attached to the membrane in order to identify common tick-borne Babesia, Theileria, Anaplasma and Ehrlichia. Probes were provided by the Midland Certified Reagent Company (Texas, USA).

\section{Sequencing}

In order to confirm the results obtained by PCR and $\mathrm{RLB}$, a total of 10 amplicons consist of $B$. canis $(\mathrm{n}=1)$, T. annulata $(\mathrm{n}=1)$, A. platys $(\mathrm{n}=2)$ and E. canis $(\mathrm{n}=6)$

Table 1 The frequency of tick-borne pathogen detected by RLB from samples at locations

\begin{tabular}{|c|c|c|c|c|c|c|}
\hline \multirow[t]{2}{*}{ Province } & \multirow{2}{*}{$\begin{array}{l}\text { No. } \\
\text { tested }\end{array}$} & \multicolumn{4}{|c|}{ Identified pathogen } & \multirow[t]{2}{*}{ Total } \\
\hline & & B. canis & T. annulata & A.platys & E. canis & \\
\hline Elazığ & 150 & - & - & - & - & - \\
\hline Diyarbakır & 63 & - & - & - & 10 & $10(15.9 \%)$ \\
\hline Erzurum & 126 & 1 & - & - & - & $1(0.8 \%)$ \\
\hline Ankara & 49 & - & - & - & - & - \\
\hline Nevşehir & 51 & - & - & - & - & - \\
\hline Adapazarı & 65 & - & - & - & - & - \\
\hline İzmit & 69 & - & & - & - & - \\
\hline Mersin & 74 & - & 1 & 2 & 5 & $6(8.1 \%)^{*}$ \\
\hline Giresun & 50 & - & - & - & 14 & $14(28.0 \%)$ \\
\hline İzmir & 60 & - & - & 2 & 8 & $10(16.7 \%)$ \\
\hline Total & 757 & $1(0.1 \%)$ & $1(0.1 \%)$ & $4(0.5 \%)$ & 37 (4.9\%) & $41(5.4 \%)$ \\
\hline
\end{tabular}

\footnotetext{
* Two samples were co-infected with A.platys and E. canis.
} 
Table 2 Distribution and frequency a of tick-borne pathogens in domestic dogs, detected by DNA amplification and reverse line blotting

\begin{tabular}{llll}
\hline Infection status & Identified pathogens & $\mathbf{n}$ & $\%$ \\
\hline Single infection & Ehrlichia canis & 35 & 4.6 \\
& Anaplasma platys & 2 & 0.3 \\
& Babesia canis canis & 1 & 0.1 \\
& Theileria annulata & 1 & 0.1 \\
Mixed infection & Ehrlichia canis + Anaplasma platys & 2 & 0.3 \\
PCR-RLB positive & any parasite (Theileria/Babesia, & 41 & 5.4 \\
& Anaplasma/Ehrlichia) & & \\
Negative & & 716 & 94.6 \\
Total & & 757 & 100 \\
\hline
\end{tabular}

were chosen for sequencing. They were selected on the basin of geographic locations where samples were collected (Mersin, Giresun, İzmir, Diyarbakır, Erzurum). The generated DNA fragments were purified with a PCR purification kit (Qiagen, Hilden, Germany) and sequenced directly in an automated DNA sequencer. DNA sequences obtained were evaluated with Chromas Lite software, version 2.01 (Technelysium Pty Ltd) and compared for similarity to sequences deposited in GenBank. Primer was deleted from DNA sequences prior to BLAST comparison.

\section{Statistical analysis}

Fisher's exact test was used to evaluate differences among prevalence of tick-borne pathogens and host gender, age, and origin. The test was performed using Epi Info software program, version 6. Statistical significance was defined as $\mathrm{p}<0.05$.

\section{Results}

DNA quantification and sensitivity of the PCR based RLB The DNA concentration ranged from 11.4 to 32.7 (median, 19.9) $\mathrm{ng} / \mu \mathrm{L}$. The $\mathrm{A} 260 \mathrm{~nm} / \mathrm{A} 280 \mathrm{~nm}$ ratios of the same extracts ranged from 1.30 to 2.12 (median, 1.60). In the positive control DNA serial dilution test, the detection limit of the assay was found to be $10^{-3}$ and $10^{-6}$ for E. canis and B. canis, respectively.

\section{Prevalence of tick-borne pathogens in dogs}

With blood smear examination, all slides were negative for piroplasms (Babesia/Theileria) and inclusion bodies (Anaplasma/Ehrlichia). Babesia/Theileria spp. DNA (hypervariable V4 region of the 18S rRNA gene) was amplified by RLBF2/RLBR2 primers in 2/757 (0.3\%) dogs, while Anaplasma/Ehrlichia spp. DNA (V1 region of the 16S rRNA gene) was amplified by $16 \mathrm{~S} 8 \mathrm{FE} / \mathrm{B}-\mathrm{GA} 1 \mathrm{~B}$ primers in 39/757 (5.1\%) dogs. PCR performed on a negative control did not yield any product on agarose gel. All PCR positive samples showed positive signals with the corresponding specific probes linked on RLB membrane.

Frequency of tick-borne pathogen detected by RLB from samples at locations is presented in Table 1. While the highest number of positive samples was obtained from the province of Giresun with $28.0 \%$, the lowest was Erzurum in $0.8 \%$. No pathogen was detected in the province of Elazig, Ankara, Nevşehir, Adapazarı and Izmit.

Prevalence of single and combined tick-borne infections is shown in Table 2. Using RLB, 41/757 (5.4\%) of the dogs were found to be infected with one or more parasites of four tick-borne pathogens: Babesia canis, Theileria annulata, A. platys, and E. canis. Ehrlichia canis (4.9\%) was the most frequent, followed by $A$. platys (0.5\%). Babesia canis and T. annulata were each detected in $1(0.1 \%)$ dog. Mixed infections were also found; the co-existence of $E$. canis and A. platys was detected in $2(0.3 \%)$ dogs.

The distribution of tick-borne infections according to the sex, age, and location of the animal (stray, shelter, pet) is given in Table 3. No significant differences were observed between male and female dogs $(P=0.976)$. The frequency of infection was higher in adult dogs $(P=0.040)$. The frequency rate was $7.4 \%(25 / 454), 6 \%$ $(31 / 351)$ and $1.2 \%(2 / 163)$ in stray, shelter, and pet dogs, respectively. These results show lower infection prevalence in pets compared to the stray $(P=0.027)$ and shelter dogs $(P=0.009)$. The difference in infection rate of stray and shelter dogs was not significant $(P=0.602)$.

A total of 10 samples which were positive for corresponding species-specific probes were sequenced in this study. All the sequences revealed an agent species consistent with the

Table 3 Comparison of tick-borne pathogen ferquency obtained in dogs according to the gender, age and origin (stray, shelter, pet)

\begin{tabular}{|c|c|c|c|c|c|c|c|}
\hline & \multicolumn{2}{|l|}{ gender } & \multicolumn{2}{|l|}{ age } & \multicolumn{3}{|c|}{ origin (location of the animal) } \\
\hline & female & male & young & adult & stray & shelter & pet \\
\hline No. of samples & 454 & 303 & 290 & 467 & 243 & 351 & 163 \\
\hline Positive & $25(5.5 \%)$ & $16(5.3 \%)$ & $9(3.1 \%)$ & $32(6.8 \%)$ & $18(\% 7,4)$ & $21(6 \%)$ & $2(1.2 \%)$ \\
\hline \multirow[t]{2}{*}{$p(F)^{*}$} & \multirow{2}{*}{\multicolumn{2}{|c|}{$p(F)=0.976(N S)$}} & \multicolumn{2}{|c|}{$p(F)=0.040$} & \multicolumn{2}{|c|}{$p(F)=0.602(N S)$} & $p(F)=0.027$ \\
\hline & & & & & & & $p(F)=0.009$ \\
\hline
\end{tabular}

* Fisher's exact test; $p$ value; NS, Not significant. 
RLB result. Of these, five partial sequences have been deposited in GenBank under the following accession numbers: KF038322, KF038320, KP745630-KP745632.

\section{Discussion}

Tick-borne protozoa and bacteria cause clinical infections in dogs in many regions of the world, depending on distribution of the vector tick. Ehrlichia canis (4.9\%) was the most common canine tick-borne pathogen found in this study. The finding is in agreement with a previous report that $R h$. sanguineus s.l. is the most prevalent tick species in infested dogs [30]. In the Aegean region of Turkey, E. canis, A. platys, and A. phagocytophilium were observed in $41.5 \%, 39.4 \%$, and $52 \%$ of sampled dogs, respectively [22]. The low prevalence values were reported here for rickettsial infections (4.9\% for E. canis and $0.5 \%$ for A. platys) when compared to the findings of the previous study [22]. Furthermore, the RLB assay conducted here contained a probe to detect $A$. phagocytophilum, but the results were negative. There was no information regarding the clinical status of the dogs sampled in the Aegean study [22], but healthy dogs were sampled in the present study and the sample type might therefore be responsible for the great differences between both studies. Another plausible explanation may be the lack of data about the analytical sensitivities of the methodologies used in both studies. Also, seasonal and geographical differences might have contributed to this.

Tick transmitted infections generally involve multiple pathogens $[31,32]$. In a study conducted in the Aegean region, 8 of 10 dogs that were naturally infected with Hepatozoon canis were found to also exhibit coexisting E. canis, A. platys, and A. phagocytophilum infections [33]. In this study, mixed infections of $A$. platys and E. canis were observed.

Canine babesiosis caused by B. canis is commonly observed in central Europe and Russia. Its distribution has expanded towards the north in recent years, and it is reported in Norway and Holland [3]. Babesia canis is transmitted by Dermacentor reticulatus, and the distribution area of the parasite is directly related to the presence of this tick species [2]. Although B. gibsoni has been observed in dogs in Turkey [24], neither babesiosis associated with $B$. canis nor the existence of $D$. reticulatus was reported in Turkey until 2013, when both the parasite and its vector were reported in 3 dogs in the East Anatolian region of Turkey [25]. In the present study, B. canis was observed in one of the blood samples collected from this region. These findings demonstrate that $B$. canis and $D$. reticulatus have formed a permanent population, at least in the eastern part of Turkey.

Tropical theileriosis caused by T. annulata is a widespread disease of cattle in Turkey $[34,35]$. This protozoon is transmitted by Hyalomma ticks. In this study, T. annulata was detected in a single dog. The finding is not surprising, as previous works have reported some piroplasm species in mammals other than their specific hosts [36-40]. Moreover, the infection by $T$. annulata has been previously reported in dogs from Iran [41].

In this study, the frequency of tick-borne infections was higher in adult dogs $(6.85 \%)$ than young (3.10\%), similar to findings of de Miranda et al. [42]. This can be explained by the fact that adult animals have greater exposure to tick-borne pathogens than do the young animals, and that the pathogens persist in the host for an extended time after the acute infection is resolved. On the other hand, some studies have reported that the prevalence of infection is not associated with the age of the host [43], implying that factors such as vector intensity and geographic distribution also influence the prevalence of tick-borne infections.

\section{Conclusions}

Babesia canis, T. annulata, A. platys, and E. canis species were identified at the molecular level in dogs in several provinces of Turkey, with $E$. canis being the most common species among tick-borne pathogens. Detailed studies should be conducted regarding the existence and prevalence of B. canis and D. reticulatus in eastern Turkey.

\section{Competing interests}

The authors declare that they have no competing interests.

\section{Authors' contributions}

MA designed the study, carried out all the molecular genetic studies and prepared the manuscript. SÖ and KA participated in the molecular genetic studies. MA, SÖ, NDSI, KA, IB, AEU, AK, SŞ and ND collected the samples. All authors read and approved the final manuscript.

\section{Acknowledgements}

This work was supported financially by a grant (110 O 870) from the Scientific and Technical Research Council of Turkey (TUBITAK). We thank all veterinarians, technicians, and animal breeders in the region for their assistance in sample collection.

\section{Author details}

'Department of Parasitology, College of Veterinary Medicine, Firat University, 23119 Elazig, Turkey. ${ }^{2}$ Department of Parasitology, College of Veterinary Medicine, Cumhuriyet University, Sivas, Turkey. ${ }^{3}$ Department of Parasitology, College of Veterinary Medicine, Dicle University, Diyarbakır, Turkey. ${ }^{4}$ Department of Parasitology, College of Veterinary Medicine, Atatürk University, Erzurum, Turkey. ${ }^{5}$ Department of Parasitology, Ceyhan Veterinary Medicine, Cukurova University, Adana, Turkey. ${ }^{6}$ Department of Internal Medicine, College of Veterinary Medicine, Atatürk University, Erzurum, Turkey.

Received: 17 November 2014 Accepted: 24 February 2015

Published online: 14 March 2015

\section{References}

1. Chomel B. Tick-borne infections in dogs-An emerging infectious threat. Vet Parasitol. 2011;179:294-301

2. Solano-Gallego L, Baneth G. Babesiosis in dogs and cats-Expanding parasitological and clinical spectra. Vet Parasitol. 2011;181:48-60.

3. Matijatko V, Torti M, Schetters TP. Canine babesiosis in Europe: How many diseases? Trends Parasitol. 2012;28:99-105. 
4. Berzina I, Capligina V, Baumanis V, Ranka R, Cirule D, Matise I. Autochthonous canine babesiosis caused by Babesia canis canis in Latvia. Vet Parasitol. 2013;196:515-8.

5. Kamani J, Baneth G, Mumcuoglu KY, Waziri NE, Eyal O, Guthmann Y, et al. Molecular detection and characterization of tick-borne pathogens in dogs and ticks from Nigeria. PLoS Negl Trop Dis. 2013;7:2108.

6. Schaarschmidt D, Gilli U, Gottstein B, Marreros N, Kuhnert P, Daeppen JA, et al. Questing Dermacentor reticulatus harbouring Babesia canis DNA associated with outbreaks of canine babesiosis in the Swiss Midlands. Ticks Tick-Borne Dis. 2013;4:334-40.

7. Little SE. Ehrlichiosis and anaplasmosis in Dogs and cats. Vet Clin N Am Small Anim Pract. 2010;40:1121-40.

8. De Tommasi AS, Otranto D, Dantas-Torres F, Capelli G, Breitschwerdt EB, De Caprariis D. Are vector-borne pathogen co-infections complicating the clinical presentation in dogs? Parasitol Vectors. 2013;6:97.

9. Harrus S, Waner T, Bjöerdorff A, Shaw S. Ehrlichiosis and anaplasmosis. In: Shaw ES, Day MJ, editors. Artrhropod-borne infectious diseases of the dogs and cats. London NW11 7DL, UK: Manson Publishing Ltd; 2005. p. 120-33.

10. Irwin PJ. Canine babesiosis: from molecular taxonomy to control. Parasitol Vectors. 2009;2:S4.

11. Matjila PT, Leisewitz AL, Jongejan F, Penzhorn BL. Molecular detection of tick-borne protozoal and ehrlichial infections in domestic dogs in South Africa. Vet Parasitol. 2008;155:152-7.

12. Rani PAMA, Irwin PJ, Coleman GT, Gatne M, Traub RJ. A survey of canine tick-borne diseases in India. Parasitol Vectors. 2011:4:141.

13. Laummaunwai $P$, Sriraj $P$, Aukkanimart R, Boonmars T, Boonjaraspinyo $S$, Sangmaneedet $\mathrm{S}$, et al. Molecular detection and treatment of tick-borne pathogens in domestic dogs in Khon Kaen, northeastern Thailand. Southeast Asian J Trop Med Public Health. 2014;45:1157-66.

14. Otranto D, Testini G, Dantas-Torres F, Latrofa MS, Diniz PP, De Caprariis D, et al. Diagnosis of canine vector-borne diseases in young dogs: a longitudinal study. J Clin Microbiol. 2010;48:3316-24.

15. Schouls LM, Ingrid Van De P, Rijpkema SGT, Schot CS. Detection and identification of Ehrlichia, Borrelia burgdorferi sensu lato, and Bartonella species in Dutch Ixodes ricinus Ticks. J Clin Microbiol. 1999;37:2215-22.

16. Altay K, Dumanli N. Survey of Theileria parasites of sheep in eastern Turkey using polymerase chain reaction. Small Rum Res. 2005;60:289-93.

17. Aktas M, Altay K, Dumanli N. Determination of prevalence and risk factors for infection with Babesia ovis in small ruminants from Turkey by polymerase chain reaction. Parasitol Res. 2007;100:797-802.

18. Aktas M, Altay K, Dumanli N. Molecular detection and identification of Anaplasma and Ehrlichia species in cattle from Turkey. Ticks Tick-Borne Dis. 2011;2:62-5.

19. Altay K, Aktas M, Dumanli N. Detection of Babesia ovis by PCR in Rhipicephalus bursa collected from naturally infested sheep and goats. Res Vet Sci. 2008;85:116-9.

20. Altay K, Aktas M, Dumanli N, Aydin MF. Evaluation of a PCR and comparison with RLB for detection and differentiation of Theileria sp. MK and other Theileria and Babesia species of small ruminants. Parasitol Res. 2008;103:319-23.

21. Altay K, Dumanli N, Aktas M. A study on ovine tick-borne hemoprotozoan parasites (Theileria and Babesia) in the East Black Sea Region of Turkey. Parasitol Res. 2012;111:149-53.

22. Karagenc T, Hosgor M, Bilgic HB, Pasa S, Kirli G, Eren H. The determination of the prevalence of E. canis, A. phagocytophila, A. platys with nested PCR in dogs in the Aegean Region. Izmir, Turkey: 14th National Parasitology Congress; 2005. p. 18-25.

23. Ulutaş B, Bayramlı G, Ulutaş PA, Karagenç T. First case of Anaplasma (Ehrlichia) platys infection in a dog in Turkey. Turk J Vet Anim Sci. 2007;31:279-81.

24. Aysul N, Ural K, Ulutaş B, Eren H, Karagenc T. First detection and molecular identification of Babesia gibsoni in two dogs from the Aydın Province of Turkey. Turk J Vet Anim Sci. 2013;37:226-9.

25. Gökçe E, Kırmızıgül AH, Taşcı GT, Uzlu E, Gündüz N, Vatansever Z. The first time clinical and parasitological determination of Babesia canis canis in Dogs in Turkey. Kafkas Univ Vet Fac J. 2013;19:717-20.

26. Aktas M. A survey of ixodid tick species and molecular identification of tick-borne pathogens. Vet Parasitol. 2014;200:276-83.

27. Alper HC, Rotherham ID. A review of the forest vegatation of Turkey: Its status past and present and its future conservation. Biol Environ Proc R Irısh Acad. 2006;106B:343-54.
28. Gubbels JM, De Vos AP, Van der Weide M, Viseras J, Schouls LM, De Vries E, et al. Simultaneous detection of bovine Theileria and Babesia species by reverse line blot hybridization. J Clin Microbiol. 1999;37:1782-9.

29. Aydin MF, Aktas M, Dumanli N. Molecular identification of Theileria and Babesia in sheep and goats in the Black Sea Region in Turkey. Parasitol Res. 2013;112:2817-24.

30. Aktas M, Ozübek S, Ipek DN. Molecular investigations of Hepatozoon species in dogs and developmental stages of Rhipicephalus sanguineus. Parasitol Res. 2013;112:2381-5.

31. Sainz A, Roura X, Miró G, Estrada-Peña A, Kohn B, Harrus S, et al. Guideline for veterinary practitioners on canine ehrlichiosis and anaplasmosis in Europe. Parasitol Vectors. 2015;8:75.

32. De Tommasi AS, Otranto D, Furlanello T, Tasca S, Cantacessi C, Breitschwerdt EB, et al. Evaluation of blood and bone marrow in selected canine vector-borne diseases. Parasitol Vectors. 2014;7:534.

33. Paşa S, Kıral F, Karagenc T, Atasoy A, Seyrek K. Description of dogs naturally infected with Hepatozoon canis in the Aegean region of Turkey. Turk J Vet Anim Sci. 2009;33:289-95.

34. Aktas M, Sevgili M, Dumanli N, Karaer Z, Cakmak A. Elazig, Malatya ve Tunceli illerinde tropikal theileriosisin seroprevalans. Turk J Vet Anim Sci. 2001;25:359-63 (Turkish).

35. Aktas M, Dumanli N, Cetinkaya B, Cakmak A. Field evaluation of PCR in detecting Theileria annulata infection in cattle in the east of Turkey. Vet Rec. 2002;150:548-9.

36. Criado-Fornelio A, Martinez-Marcos A, Buling-Sarana A, Barba-Carretero JC. Molecular studies on Babesia, Theileria and Hepatozoon in southern Europe. Part I. Epizootiological aspects. Vet Parasitol. 2003;113:189-201.

37. Criado-Fornelio A, Martinez-Marcos A, Buling-Sarana A, Barba-Carretero JC. Molecular studies on Babesia, Theileria and Hepatozoon in southern Europe. Part II. Phylogenetic analysis and evolutionary history. Vet Parasitol. 2003;114:173-94

38. Nagore D, Garcia-Sanmartin J, Garcia-Pérez AL, Juste RA, Hurtado A. Detection and identification of equine Theileria and Babesia species by reverse line blotting: epidemiological survey and phylogenetic analysis. Vet Parasitol. 2004;23:41-54.

39. Criado A, Martinez J, Buling A, Barba JC, Merino S, Jefferies R, et al. New data on epizootiology and genetics of piroplasms based on sequences of small ribosomal subunit and cytochrome b genes. Vet Parasitol. 2006;142:238-47.

40. Adamu M, Troskie M, Oshadu DO, Malatji DP, Penzhorn BL, Matjila PT. Occurrence of tick-transmitted pathogens in dogs in Jos, Plateau State, Nigeria. Parasite. Parasitol Vectors. 2014;7:119.

41. Bigdeli M, Rafie SM, Namavari MM, Jamshidi S. Report of Theileria annulata and Babesia canis infections in dogs. Comp Clin Pathol. 2012;21:375-7.

42. De Miranda RL, O'Dwyer LH, De Castro JR, Metzger B, Rubini AS, Mundim AV, et al. Prevalence and molecular characterization of Hepatozoon canis in dogs from urban and rural areas in Southeast Brazil. Res Vet Sci. 2014;97:326-9.

43. Gomes PV, Mundim MJS, Mundim AV, Ávila DF, Guimarães EC, Cury MC. Occurrence of Hepatozoon sp. in dogs in the urban area originating from a municipality in southeastern Brazil. Vet Parasitol. 2010;174:155-61.

\section{Submit your next manuscript to BioMed Central and take full advantage of:}

- Convenient online submission

- Thorough peer review

- No space constraints or color figure charges

- Immediate publication on acceptance

- Inclusion in PubMed, CAS, Scopus and Google Scholar

- Research which is freely available for redistribution 